\title{
Stabilization of compressed earth block clayey materials from Adrar (Algeria) by lime and crushed sand
}

\author{
Abbou M 1,2, , Semcha A 1,2, Kazi-Aoual F 2 \\ Université Ahmed Draia,Adrar, Algeria. \\ 2 Laboratoire des Matériaux LABMAT, L'Ecole Nationale Polytechnique d'Oran - Maurice Audin, Algeria. \\ Corresponding Author: moh.abbou@univ-adrar.dz
}

Received: 01-02-2020

Accepted: 25-03-2020

\begin{abstract}
The objective of this article is to determine the physical and mechanical properties of stabilized compressed earth bricks (SCEB), made from a mixture of clay with crushed sand, and stabilized by lime. In this study, we first examine the identifying properties of raw materials. Then an experimental study was conducted with cylindrical test pieces of a mixture of clay and crushed sand prepared by the addition of lime and statically compaction, to study the physical and mechanical characteristics of the mixture. The experimental study shows that for use as a building material, the clay mixture with $30 \%$ crushed sand and stabilized with $4 \%$ and $6 \%$ lime is the optimum mixture for as a stabilized compressed earth bricks.
\end{abstract}

Key words: Clay, crushed sand, Lime, SCEB, physico-mechanical properties.

\section{Introduction}

For almost 10,000 years, the earth has been one of the main building materials used on our planet. More than a third of the world's inhabitants today live in earthen habitats. There are very many earth construction methods which reflect the identity of the place; like adobe frames, compressed blocks, rammed earth ... (Houben and Guillaud, 2006).

In addition, several studies are devoted to the CEB technique and the various modes of stabilization (Rigassi, 1995), for the improvement of mechanical resistance as well as durability (porosity, resistance to erosion etc): (Winterkorn, 1975; United Nations, 1992; Symons et al., 1999; González-López et al., 2018). In these studies, it emerges that chemical lime treatment is one of the solutions adopted. The effect of adding lime causes physico-mechanical changes on treated soils (Le Roux and Rivière, 1969; Bell, 1996; Cabane, 2004; Malkanthi et al., 2020). These changes are very slow at room temperature. It takes several months or even years before its effects can be appreciated (Arabi and Wild, 1989; Rao and Shivananda, 2005; Lasladj, 2009; Cabane, 2004). In contrast, the granular composition of the earth is influenced on the mechanical properties and durability of SCEB (Mkaouar et al., 2019; Muhwezi and Achanit, 2019).

Like other localities in the Adrar region (southern Algeria), earthen constructions made from local materials have proven their existence for millennia. In this context, experimental work is carried out in particular in the design of a stabilized compressed earth block (SCEB). The latter expresses the modern evolution of the block of molded earth (the Adobe), with the aim of inscribing a new technique of raw clay construction in the Adrar region which is known by the Adobe technique. This technique of compressed and stabilized earth brick, based on clay offers a new opportunity to the Saharan environment and meets the criteria of sustainability. 


\section{Materials and technical methods}

\subsection{Identification of the materials used}

The study targeted two materials that are found in abundance in the Adrar region: the first is clay soil and the second is crushed sand from local quarries.

\subsubsection{The clay}

The studied clay is localized in the lower cretaceous commonly called intercalary continental. In the first part of the Lower Cretaceous sediment area are covered by a thick layer of sand deposits, silt, sandstone debris, quartz pebble and locally anhydrite). The clay deposit of the Adrar region (Sbâa) in Algeria is located at few kilometers north of the town of Adrar (East of the national road $\mathrm{N}^{\circ} 06$ ). The material has a red color.

However, two complementary methods, wet sieving and sedimentation analysis, respectively according, to XP P94-041(1995) and NF P94-057(1992), determined the particle size distribution.

The plastic properties of the fine fraction, particles smaller than $400 \mu \mathrm{m}$, were measured as defined in NF P94-051(1993). The density of the solid particles (Gs) was measured using a pycnometer NF P 94-054(1992). Moreover, analyzes of the chemical compositions are carried out at the Center for Studies and Technological Services in the Building Materials Industry laboratory in Boumerdès (Algeria). The reference used for the choice of earth proposed for the manufacture of SCEB is based on the recommendations of CRATerre (International Center for Earth Construction), Houben and Guillaud (1995), and the standard XP P 13-901.

Table 1. Geotechnicals properties of the clay used.

\begin{tabular}{|c|c|}
\hline Proprieties & Values \\
\hline \hline Sand $(>0,02 \mathrm{~mm})$ & $9 \%$ \\
\hline Silt $(0,02-0,002 \mathrm{~mm})$ & $54 \%$ \\
\hline Clay $(<0,002 \mathrm{~mm})$ & $37 \%$ \\
\hline Liquid limit WL & $81 \%$ \\
\hline Plastic limit WP & $34 \%$ \\
\hline plastic index IP & 47 \\
\hline VB & 8 \\
\hline Specific density $\gamma \mathrm{s}$ & $2.6 \mathrm{~g} / \mathrm{cm}^{3}$ \\
\hline
\end{tabular}

Table 2. Chemical Composition of the clay of the Adrar.

\begin{tabular}{|c|c|}
\hline Compounds & Values (\%) \\
\hline $\mathrm{SO}_{4}{ }^{2-}$ & 0.41 \\
\hline $\mathrm{CaCO}_{3}$ & 3.6 \\
\hline $\mathrm{Cl}^{-}$ & 0.14 \\
\hline Insoluble $\left(\mathrm{SiO}_{2}-\mathrm{Al}_{2} \mathrm{O}_{3}-\mathrm{Fe}_{2} \mathrm{O}_{3}-\mathrm{CaO}-\mathrm{MgO}\right)$ & 95.92 \\
\hline
\end{tabular}

\subsubsection{Crushed Sand}

The quarry is located on the southern part of the center of the city of Adrar. The trails leading to the deposit are easy to access. 
Table 3. Physicals properties of the crushed sand.

\begin{tabular}{|l|l|}
\hline Proprieties & Values \\
\hline \hline Equivalent de sable & $36.49 \%$ \\
\hline Specific density & $2.5 \mathrm{~g} / \mathrm{cm}^{3}$ \\
\hline Apparent density & $1.46 \mathrm{~g} / \mathrm{cm}^{3}$ \\
\hline Finesse Model & 2.79 \\
\hline
\end{tabular}

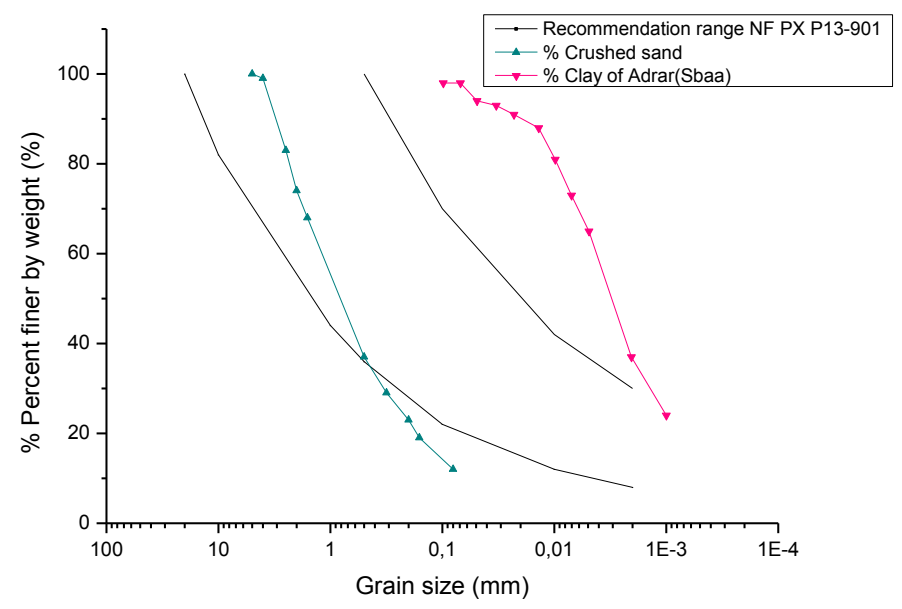

Fig. 1. Particle size distribution of clay and crushed sand.

\subsubsection{Lime}

The lime used in this study is the slaked lime $\mathrm{Ca}(\mathrm{OH})_{2}$, obtained after the hydration of quicklime $(\mathrm{CaO})$ produced in the wilaya of Ghardaia.

\subsection{Technical methods}

\subsubsection{Formulation}

Houben and Guillaud (1989) highlight some feedback on the formulation of soil-based products and more specifically compressed earth bricks. Reference particle size zones are used to determine the ability of a soil to be compressed or not.

According to the standard XP13-901, (2001) and the recommendation of the CRATerre, the approach is to bring on the same granulometric diagram the curves of sandy and clay soils as well as the outline of the desired optimal curve. This method gives the proportion of the finest earth to be mixed with the coarsest earth to obtain a texture that approaches the optimal curve, which can be the midline of the spindle.

For the preparation of the mixture (clay and crushed sand), a study on different mixtures is carried out. As a result, the mixture is composed of $30 \%$ clay and $70 \%$ crushed sand, has shown a composition that approaches it to the middle line of the recommended spindle.

The initial amount of lime required to stabilize the blends is $4 \%$ by dry weight of the mixture, was determined according to the method developed by Eades and Grim (1966), ASTM D 627699a (1996). The PH measurement test assesses the lime content needed to produce a saturated solution of lime in a soil suspension in water and to fully satisfy the ion exchange. The $\mathrm{pH}$ threshold is set at 12.4. The amount of lime to obtain this $\mathrm{pH}$ is known as the point of attachment of lime. From this $\mathrm{pH}$ value, the additional lime is supposed to be available for the development of pozzolanic reactions. So lime dosages of $2 \% ; 4 \% ; 6 \%$ are chosen for the mixtures. 


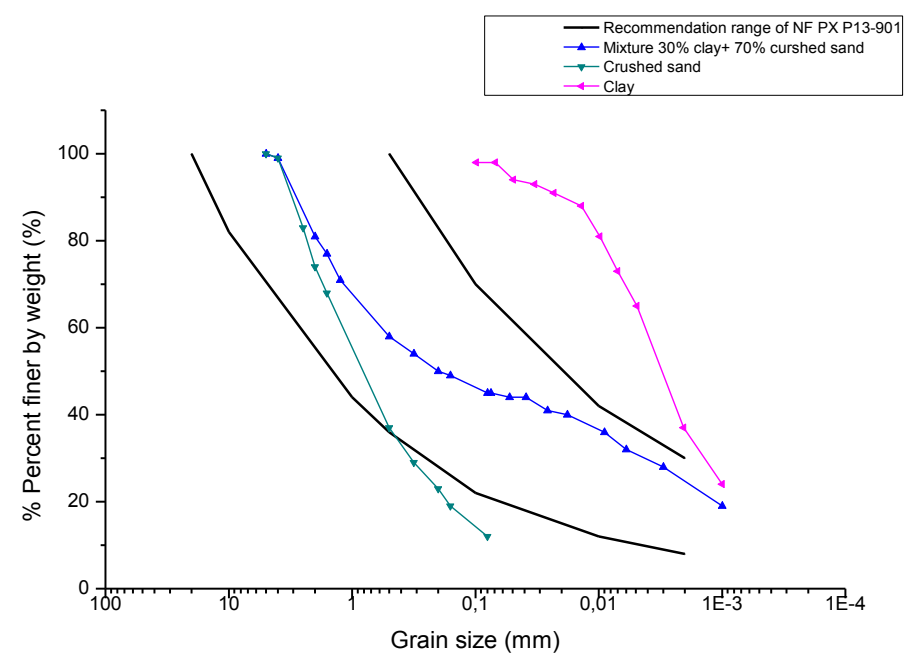

Fig. 2. Particle-size distribution of the clay and crushed sand mixtures.

\subsubsection{Optimization, design and manufacture of test specimens}

According to studies by Mesbah et al. (1999) and P'Kla (2002), static compaction is better suited to clay soils, and the determination of optimal water content for CEB from the Proctor test is inappropriate because compaction is not the same as that of a static compaction used for the manufacture of the CEB.

However, this theme is one of the objectives of this study. To optimize the water content of the mixtures, we have also based on the study conducted by Olivier and Mesbah (1986), which showed that regardless of the materials, the stabilization mode or the compression forces implemented, the optimum water content of manufacturing Wocs (OCS: Optimum static compaction), correspond to both the maximum dry density and the maximum compressive strength. The raw earth mixtures were compacted under a pressure of $3 \mathrm{MPa}$, using a press with a constant speed is equal to $1.27 \mathrm{~mm} / \mathrm{min}$. Before compacting, the raw material is mixed with a predetermined amount of water in a kneader for 15 minutes. This time is sufficient to ensure a good homogeneity of the mixture (Kouakou and Morel, 2009).

The wet sample is then placed in a sealed environment to prevent loss of water for 24 hours. This step allows the homogeneous redistribution of the water content. Finally, the wet material is introduced into a hollow cylindrical mold (Fig. 3), in order to obtain cylindrical test pieces (10 $\times 5$ ) $\mathrm{cm}$ of slenderness equal to 2 , for each mixture.

However, these specimens do not have the same dimensions as those used for concrete since our maximum particle size is less than $5 \mathrm{~mm}$ ( $\mathrm{P}^{\prime} \mathrm{Kla}, 2002$ ) and compacted by applying the pressure level fixed by a press. The material is compacted vertically at the top and at the bottom by means of two cylindrical pistons (Fig.3). Five test pieces were made for each mixture.

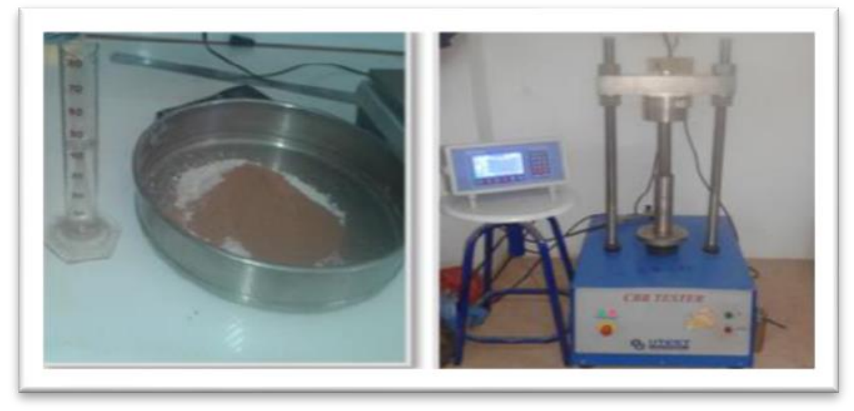

Fig. 3. Optimization of the water content of the crushed sand clay mixture. 


\subsubsection{Condition of cure}

All test specimens made from the crushed clay-sand mixture are stored in the laboratory at a temperature, $\mathrm{T}=20^{\circ} \mathrm{C}$ to a constant mass (Fig.4.A).

In addition, the covered cylindrical test pieces are stored in an oven at a temperature $\mathrm{T}=65^{\circ} \mathrm{C}$. for different durations of 7 days, 14 days, 28 days and 90 days (Fig.4.B). The test specimens concerned by this mode are the sand-cracked clay mixtures plus the different percentages of the slaked lime. To study of the effect of cure time on the mechanical properties of mixtures.
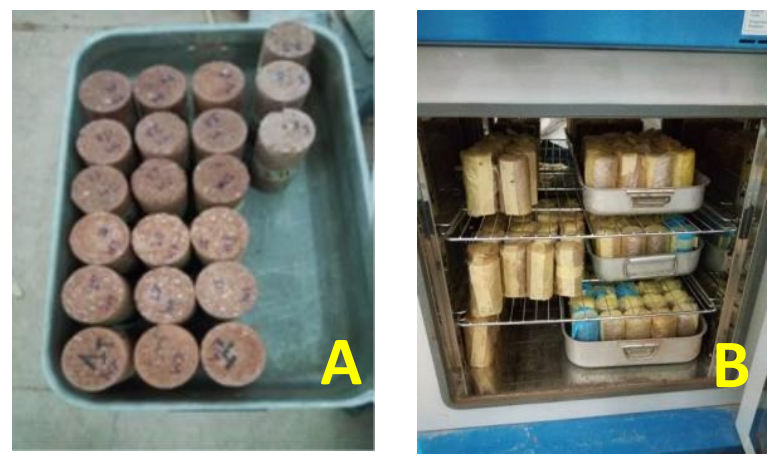

Fig. 4. The method of conservation of the test pieces.

\section{Results end discussions}

\subsection{Optimum water content and maximum density}

Fig. 5 shows the optimization obtained for the static Compression mixture of the order of $3 \mathrm{MPa}$. The optimization method is similar to the method used by Olivier and Mesbah (1986) when static compaction is used, the same method was used to optimize the clay-sand mixture with lime.

In this work, the optimal water content and the maximum density of the mixture constituted by local materials are optimized. Fig. 6 shows that increasing the proportion of lime on the mixture caused an offset of the optimal water content of compaction to higher water contents and a decrease in dry densities. This modification of the optimum is similar with the study conducted by Le Roux and Rivière (1969) on the introduction of lime into a soil of a different clay nature.

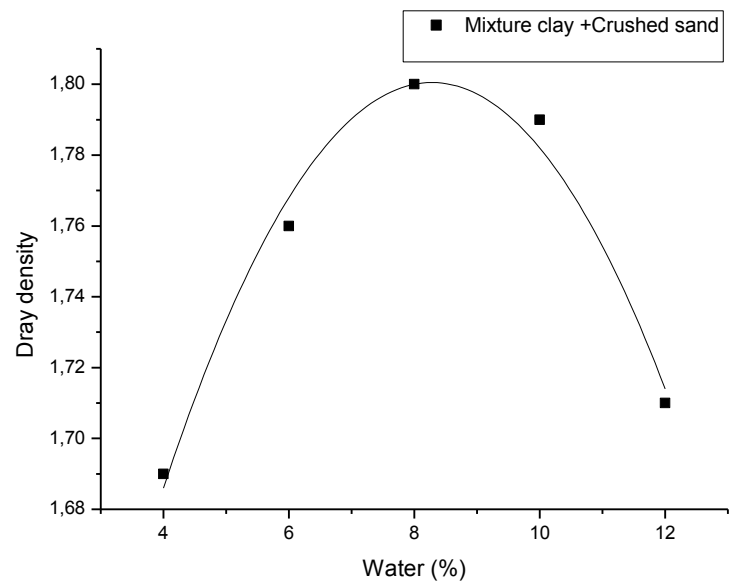

Fig. 5. Optimization of the water content of the crushed sand clay mixture. 


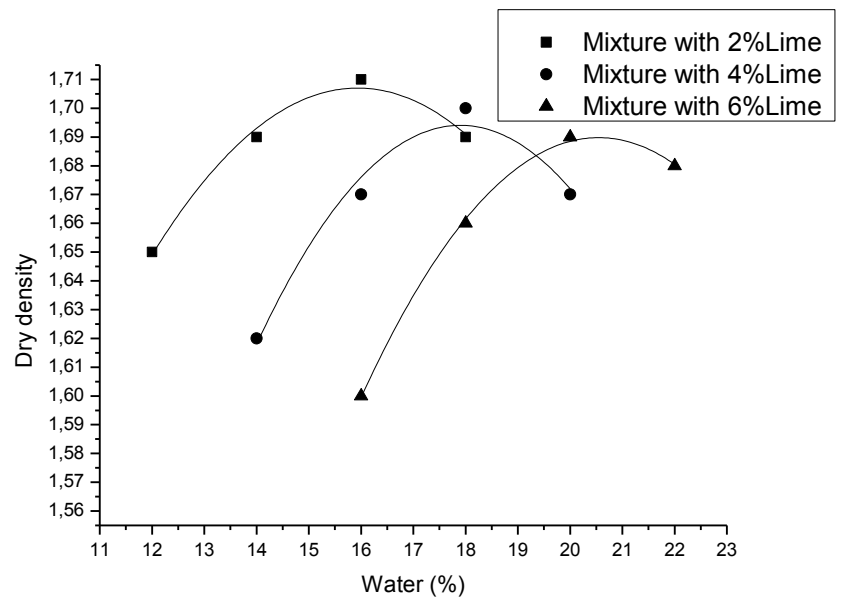

Fig. 6. Optimization of the water content of the mixture with slaked lime.

\subsection{Mechanical properties}

\subsubsection{Dry compressive strength}

Fig.7 shows the effect of lime through the results of variation in dry compressive strength as a function of lime dosage at the age of 7, 14, and 28 days of cure. Through the figure below we note that for a stabilization of $2 \%, 4 \%$ and $6 \%$ we have resistances to the dry compression at 28 days respectively of $3.2,4.59$ and $5.6 \mathrm{MPa}$.

According to these results, it is noted that there is an increase in the dry compressive strength as a function of the lime content for the crushed clay-sands mixture. Indeed, at the age of 28 days, there is formation of portlandite and formation in very small quantities, hydrated calcium silicate and aluminates phases that ensure the bonds between the particles and enhance the mechanical performance of the mixture. These findings were observed by the authors Bell (1996), Maubec (2010).

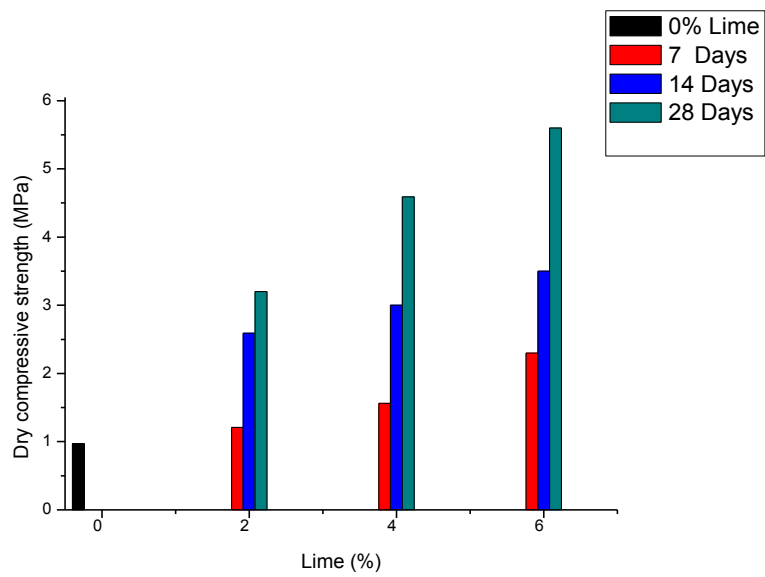

Fig. 7. Dry compressive strength of lime-based test specimens based on lime-slurry dosage, and age of preservation.

\subsubsection{Dry tensile strength}

The results of the tensile splitting test are presented in Fig. 7, which shows an increase in the tensile strength of the test pieces as a function of the increase in the dosage of slaked lime at the age of 90 days cure. 
However, for stabilization with slaked lime, the tensile strength of the cylinders (mixtures) gradually increases. The maximum average resistance is reached with a content of $6 \%$ of lime that is $1.4 \mathrm{MPa}$.

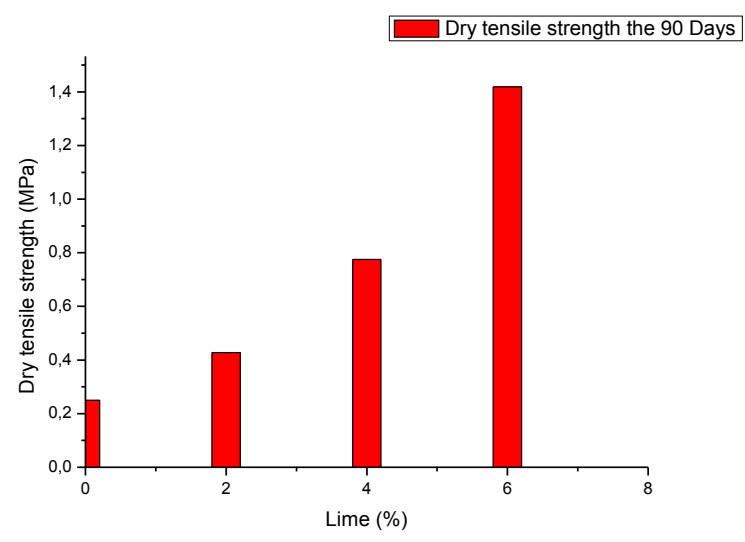

Fig. 8. Tensile strength of specimens as a function of $\mathbf{9 0 - d a y ~ s l a k e d ~ l i m e ~ d o s a g e . ~}$

\subsection{Capillary absorption}

The results show that there is a difference between specimens at the age of 28 and 90 days of cure, different assays in lime and non-stabilized specimens. For a stabilization at 2, 4 and $6 \%$ of slaked lime, the percentage of capillary absorption decreases respectively 18.53, 17.56 and $16.92 \%$ at 28 days, at $15.95,15.3$ and 14.8 at 90 days. The difference in these values is approximately $2.3 \%$ Moreover; the value of the absorption of the mixture without the addition of lime is of the order of $20.14 \%$. So, the slaked lime stabilization resulted in a more compact and less porous mix.

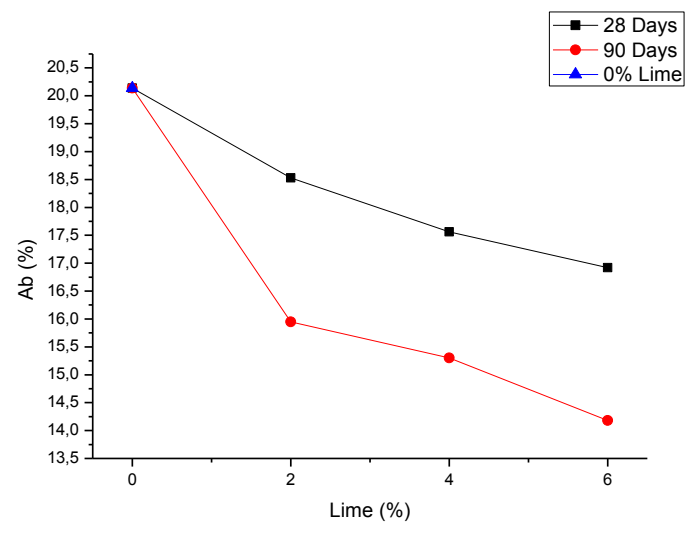

Fig. 9. Capillary absorption as a function of lime dosage at 28 and 90 days of cure.

\section{Conclusions}

The aim of this work was to study the effect of the content of slaked lime on the mechanical properties and the capillary absorption of test pieces made from local materials (Clay + Crushed Sand) statically compacted at $3 \mathrm{MPa}$. Based on the results of this experimental study, the following conclusions are drawn:

- Optimum moisture content increases with increasing rate of slaked lime.

- Dry density decreases with increasing lime rate. 
- The dry compressive strength is improved by the addition of lime that depending on the age of preservation, so the maximum value of the dry compressive strength obtained at 28 days of cure with $6 \%$ lime off is equal to $5.6 \mathrm{MPa}$.

- Increasing and improving the splitting tensile strength as the percentage of slaked lime increases. The tensile strength at 90 days of treatment obtained with a stabilization at $6 \%$ of slaked lime is equal to $1.41 \mathrm{MPa}$, while the specimens stabilized at $4 \%$ of lime extinguished at 90 days of cure gave about half of the resistance of tensile specimens stabilized at $6 \%$, is $0.77 \mathrm{MPa}$.

- For slaked lime stabilization, cylindrical samples have a small percentage for capillary absorption. This depends on the increase in lime content and the cure time.

- In view of these results, we can say that the addition of stabilizer (slaked lime) remarkably improves the mechanical characteristics of the mixture as well as the properties (durability) of the absorption.

\section{References}

Arabi M., \& Wild S. (1989). Property changes induced in clay soils when using lime stabilization. Municipal Engineer (London), 6(2), 85 - 99.

ASTM D6276-99a. (1996) Standard test method for using pH to estimate the soil-lime proportion requirement for soil stabilization. 427 American testing and materials society, Philadelphia.

Bell, F. G. (1996). Lime stabilization of clay minerals and soils. Engineering geology, 42(4), 223-237.

Cabane N (2004). Sols traités à la chaux et aux liants hydrauliques: contribution à l'identification et à l'analyse des éléments perturbateurs de la stabilisation, Thèse de Doctorat, Ecole Nationale Supérieure des Mines de St Etienne, Université Jean Monet, 182 p.

Eades, J. L., \& Grim, R. E. (1966). A quick test to determine lime requirements for lime stabilization. Highw Res Rec 139:61-72.

González-López, J. R., Juárez-Alvarado, C. A., Ayub-Francis, B., \& Mendoza-Rangel, J. M. (2018). Compaction effect on the compressive strength and durability of stabilized earth blocks. Construction and Building Materials, 163, 179-188.

Houben H., \& Guillaud H. (1989). Traité de construction en terre. 3ème ed. Parenthèse, editor. France: Habitat Ressource;. p. 355.

Houben H., \& Guillaud H. (1995). Traité de construction en terre, CRATerre. Editions Paranthèses, Marseille.

Houben H., \& Guillaud H. (2006). Traité de construction en terre. CRATerre, Edition Parenthèse,

Kouakou, C. H., \& Morel, J. C. (2009). Strength and elasto-plastic properties of non-industrial building materials manufactured with clay as a natural binder. Applied Clay Science, 44(1-2), 27-34.

Lasledj A. (2009). Traitement des sols argileux à la chaux : processus physico-chimique et propriétés géotechniques, Thèse de Doctorat, Université d'Orléans, 359 p.

Le Roux, A., \& Rivière, A. (1969). Traitement des sols argileux par la chaux. Bulletin de Liaison des Laboratoires des Ponts et Chaussées, Paris (40), 59-95.

Malkanthi, S. N., Balthazaar, N., \& Perera, A. A. D. A. J. (2020). Lime stabilization for compressed stabilized earth blocks with reduced clay and silt. Case Studies in Construction Materials, 12, e00326.

Maubec N. (2010). Approche multi-échelle du traitement des sols à la chaux études des interactions avec les argiles. Thèse de doctorat, université de Nantes, France. p217.

Mesbah, A., Morel, J. C., \& Olivier, M. (1999). Comportement des sols fins argileux pendant un essai de compactage statique: détermination des paramètres pertinents. Materials and structures, 32(9), 687-694. 
Mkaouar, S., Maherzi, W., Pizette, P., Zaitan, H., \& Benzina, M. (2019). A comparative study of natural Tunisian clay types in the formulation of compacted earth blocks. Journal of African Earth Sciences, 160, 103620.

Muhwezi, L., \& Achanit, S. E. (2019). Effect of Sand on the Properties of Compressed Soil-Cement Stabilized Blocks. Science, 4(1), 1-6.

NF P 94-05. (1993). Sols : reconnaissance et essais - Détermination des limites d'Atterberg - Limite de liquidité à la coupelle - Limite de plasticité au rouleau. AFNOR.

NF P 94-054. (1992) Sols : reconnaissance et essais - Détermination de la masse volumique des particules solide des sols - Méthodes du pycnomètre à l'eau. AFNOR.

NF P 94-057. (1992).Sols: reconnaissance et essais - Analyse granulométrique des sols - Méthode par sédimentation. AFNOR.

Olivier, M., \& Mesbah, A. (1986). Le matériau terre: Essai de compactage statique pour la fabrication de briques de terre compressées. Bull. Liaison Lab. Ponts et Chaussées, 146, 37-43.

P'Kla, A. (2002). Caractérisation en compression simple des blocs de terre comprimée (BTC) : Application aux maçonneries «BTC-Mortier de terre. Thèse de doctorat, Institut national des sciences appliquées de Lyon, France.

Rao, S. M., \& Shivananda, P. (2005). Role of curing temperature in progress of lime-soil reactions. Geotechnical \& Geological Engineering, 23(1), 79-85.

Rigassi V. (1995). Blocs de terre comprimée. Volume I. Manuel de production, CRATerre-EAG, Friedrich Vieweg \& Sohn, Braunschweig, Allemagne, $104 \mathrm{p}$.

Symons, M. G., \& Poli, D. C. (1999). Properties of Australian soils stabilised with cementitious binders. Structural Materials and Assemblies Group, University of South Australia, the Levels, South Australia.

United Nations, (1992). Earth Construction Technology. United Nations Centre for Human Settlements, Nairobi, Kenya, 200 p.

Winterkorn, H. F. (1975). Soil stabilization. In Foundation Engineering Handbook,Winterkorn, H.F. \& Fang, H.-Y., Van Nostrand Reinhold Company, 750 pp.

XP P 94-041. (1995). Sols : reconnaissance et essais -Identification granulométrique - Méthode de tamisage par voie humide. AFNOR.

XP P13-901. (2001).Blocs de terre comprimée pour murs et cloisons, Définitions -SpécificationsMéthodes d'essai- Conditions de réception 